\title{
Letter to the editor 1: Predictors of oesophageal candidiasis in persons with or without HIV infection
}

\author{
Felix Bongomin ${ }^{1,2}$, Samuel A Fayemiwo ${ }^{1,3}$
}

1. Division of Infection, Immunity and Respiratory Medicine, The University of Manchester, Manchester, M13 9PL, UK.

2. Department of Medical Microbiology and Immunology, Faculty of Medicine, Gulu University, P.O. Box 166, Gulu, Uganda. 3. University College Hospital, Department of Medical Microbiology and Parasitology, College of Medicine, Ibadan, Nigeria.

DOI: https://dx.doi.org/10.4314/ahs.v18i2.32

cite as: Bongomin F, Fayemiwo SA. Letter to the editor 1: Predictors of oesophageal candidiasis in persons with or without HIV infection. Afri Health Sci. 2018;18(2): 468-469. bttps:/ / dx. doi.org/10.4314/ abs.v18i2.32

Dear Sir,

We read with great interest the article by Mushia nd colleagues recently published in African Health Sciences ${ }^{1}$. The authors present data on predictors of endoscopically diagnosed oesophageal candidiasis (OC). Much as this is an interesting and one of the largest studies of its kind in the region, it is confusing in one respect. A major distinction between predictors of OC in HIV-infected patients and risk factors for development of OC in HIV-uninfected individuals should have been drawn in the abstract. Additionally, HIV which is a major risk factor for oesophageal candidiasis is missing in the conclusions, and its odds ratio is not only inconsistent with that provided in Table 2 of the results section, but also out of the $95 \%$ confidence interval.
OC (or Candida oesophagitis) is the most common infectious disease of the oesophagus; it is an opportunistic infection that complicates disorders associated with granulocyte and/or lymphocyte numbers and dysfunction ${ }^{2,3}$. $\mathrm{OC}$ is an AIDS-defining illness occurring in patients with advanced HIV disease and is estimated to occur in at least $5 \%$ of patients who are on antiretroviral therapy (ART) and in 20\% who are ART-naïve,5. Predictors of OC in $\mathrm{HIV}$-infected patients include low CD4 counts (typically $<50$ cells $/ \mu \mathrm{L}$ ), high HIV RNA viral load, oropharyngeal candidiasis and ART naivety ${ }^{6-8}$.

There is no published data on predictors of $\mathrm{OC}$ in HIV-uninfected patients. However, risk factors for the development of OC in HIV negative from several published studies are as summarised in Table 1.

Table 1: risk factors for the development of oesophageal candidiasis in HIV-infected and HIVuninfected patients

\begin{tabular}{|c|c|}
\hline Major risk factors & Other risk factors \\
\hline 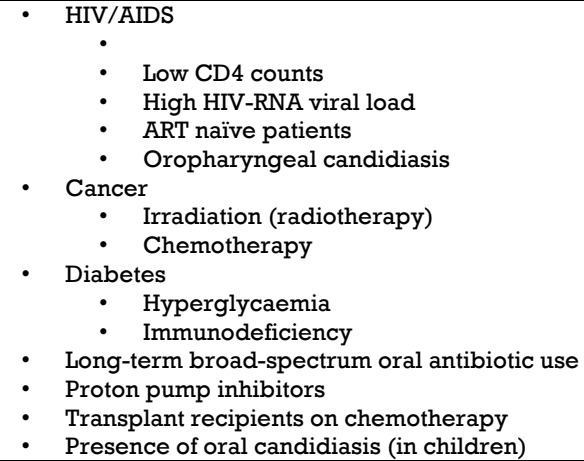 & $\begin{array}{l}\text { - } \text { Smoking } \\
\text { - } \\
\text { - Refluxolism esophagitis } \\
\text { - } \text { Inhaled corticosteroid use } \\
\text { - } \quad \text { Chrostomia (inadequate saliva) } \\
\quad \text { chronic heart failure etc.) } \\
\text { - } \quad \text { High sugar diet } \\
\text { - } \text { Increasing age } \\
\text { - Previous gastric surgeries } \\
\text { - } \quad \text { Oral steroid therapy } \\
\text { Defective neutrophil motility }\end{array}$ \\
\hline
\end{tabular}

\section{Corresponding author:}

Felix Bongomin,

Department of Medical Microbiology

and Immunology, Faculty of Medicine,

Gulu University, P.O. Box 166, Gulu, Uganda.

Tel: +44 7884440 402, Manchester, UK

Email: felix.bongomin@manchester.ac.uk

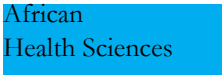

468
(C) 2018 Bongomin et al. Licensee African Health Sciences. This is an Open Access article distributed under the terms of the Creative commons Attribution License (https://creativecommons.org/licenses/by/4.0), which permits unrestricted use, distribution, and reproduction in any medium, provided the original work is properly cited. 
Despite the retrospective nature of the study, the authors have shown some important association between oesophageal candidiasis and risk factors such as diabetes and antibiotic use, though decreasing age as a risk factor as mentioned by the authors in the abstract contradicts their own data provided in Table 2 and established evidence $^{9}$. Summary Table 2 requires rigorous statistical adjustments and improvement on data presentation.

Hence, we regret that the study does not live up to its title and has failed to inform the readers on the predictors of OC both in HIV-infected and HIV-uninfected individuals; it is "a prevalence and factors associated with oesophageal candidiasis" study, as suggested in the aim rather than "predictors of oesophageal candidiasis" as currently stated in the title.

\section{Declaration of interest}

None

\section{References}

1. Mushi MF, Ngeta N, Mirambo MM, Mshana SE. Predictors of esophageal candidiasis among patients attending endoscopy unit in a tertiary hospital, Tanzania: a retrospective cross-sectional study. Afr Health Sci [Internet]. 2018 Apr 4;18(1):66. Available from: https://www.ajol. info/index.php/ahs/article/view/169134

2. Grossi L, Ciccaglione AF, Marzio L. Esophagitis and its causes: Who is "guilty" when acid is found "not guilty"? World J Gastroenterol [Internet]. 2017;23(17):3011. Available from: http://www.wjgnet.com/1007-9327/full/ v23/i17/3011.htm

3. Hassan TIY, Mahony M. Oesophageal candidiasis in an immunocompetent child. Ir Med J [Internet]. 2014 Sep;107(8):243-4. Available from: http://www.ncbi.nlm. nih.gov/pubmed/25282966
4. Buchacz K, Baker RK, Palella FJ, Chmiel JS, Lichtenstein KA, Novak RM, et al. AIDS-defining opportunistic illnesses in US patients, 1994-2007: a cohort study. AIDS [Internet]. 2010;24(10):1549-59. Available from: http://content.wkhealth.com/ linkback/openurl?sid=WKPTLP:landingpage\& an $=00002030-201006190-00017$

5. d'Arminio Monforte A, Vago L, Lazzarin A, Boldorini R, Bini T, Guzzetti S, et al. AIDS-defining diseases in $250 \mathrm{HIV}$-infected patients; a comparative study of clinical and autopsy diagnoses. AIDS [Internet]. 1992 Oct;6(10):1159-64. Available from: http://www.ncbi. nlm.nih.gov/pubmed/1334675

6. Tavitian A, Raufman JP, Rosenthal LE. Oral candidiasis as a marker for esophageal candidiasis in the acquired immunodeficiency syndrome. Ann Intern Med [Internet]. 1986 Jan;104(1):54-5. Available from: http://www.ncbi. nlm.nih.gov/pubmed/3940505

7. Saeed SA, Boyle JT. Other Diseases of the Esophagus. In: Pediatric Gastrointestinal and Liver Disease [Internet]. Elsevier; 2011. p. 255-260.e1. Available from: http://linkinghub.elsevier.com/retrieve/pii/ B9781437707748100247

8. Takahashi Y, Nagata N, Shimbo T, Nishijima T, Watanabe K, Aoki T, et al. Long-Term Trends in Esophageal Candidiasis Prevalence and Associated Risk Factors with or without HIV Infection: Lessons from an Endoscopic Study of 80,219 Patients. Andes DR, editor. PLoS One [nternet]. 2015 Jul 24;10(7):e0133589. Available from: http://dx.plos.org/10.1371/journal.pone.0133589

9. Weerasuriya N, Snape J. A study of candida esophagitis in elderly patients attending a district general hospital in the UK. Dis Esophagus [Internet]. 2006 Jun 1;19(3):18992. Available from: https://academic.oup.com/dote/article/2194918/A 